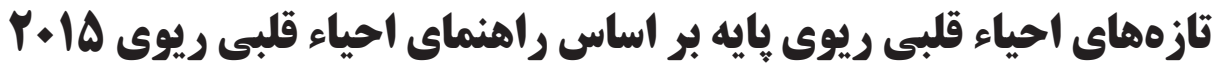

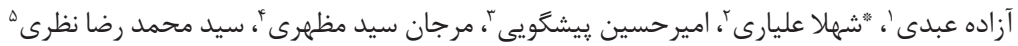

جكيده

مقدمه: از آنجا كه احياء قلبى ريوى نقش مؤثرى در كاهش ميزان مرى و مير ناشى از ايست قلبى ريوى دارد و در صورت

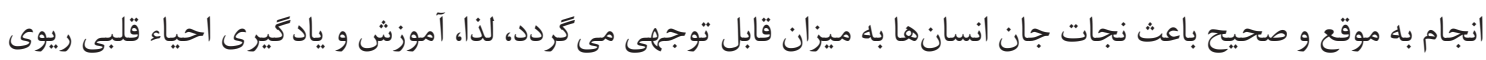

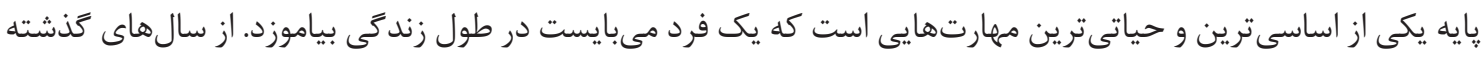

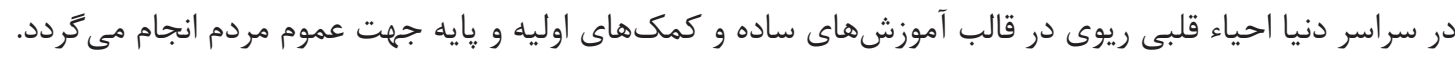

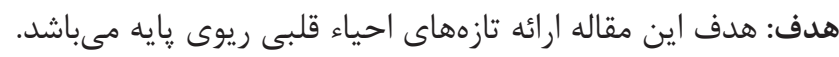

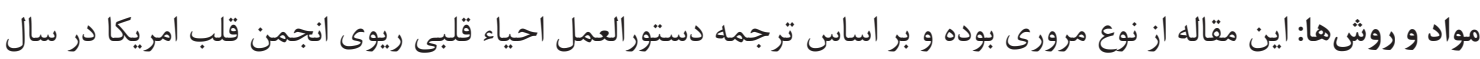

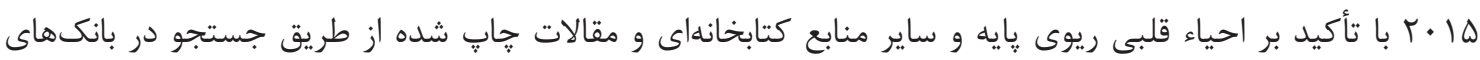

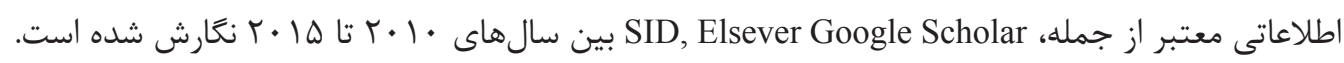
يافتها: با توجه به اينكه احياكران غيرحرفهاى و افراد آموزشديده حرفهاى نقش حياتى در احياء يايه فردى كه دهار

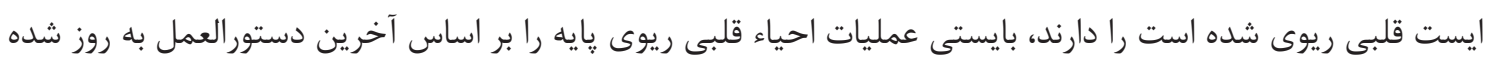

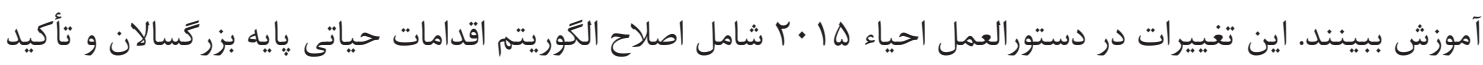

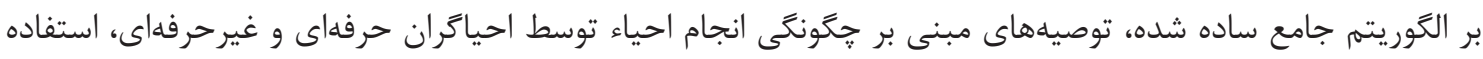

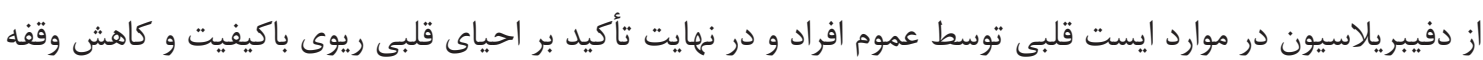
تا حد ممكن مىباشد. بحث و نتيجهَّيرى: آكاهى از احياء قلبى ريوى پايه و آَاهى از آخرين تغييرات آن جهت كليه احياكران حرفهاى و غيرحرفهاى امرى لازم و بديهى است.

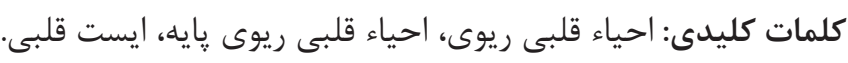

مجله علوم مر اقبتى نظامى | سال سوم | شماره | | بهار هوس|| | شماره مسلسل V | صفحات

دو دهه اخير بوده است (1)، به حدى كه سالانه در آمريكا حدود

مقدمه

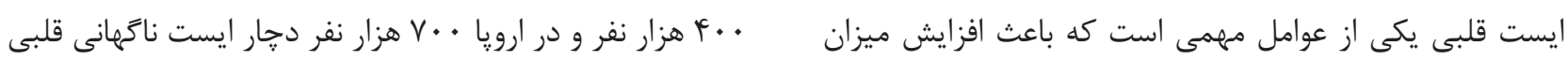

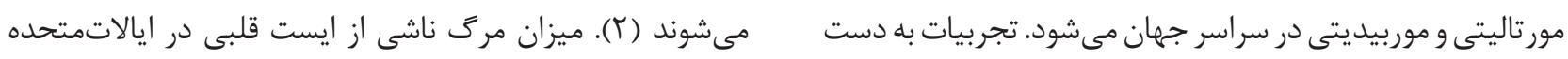

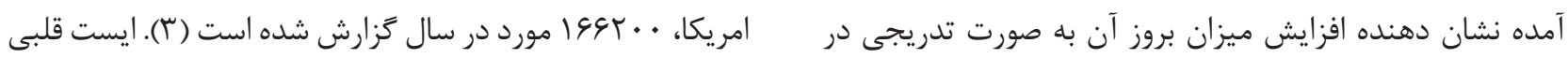

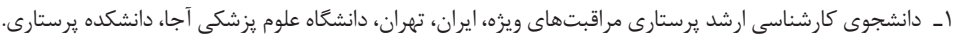

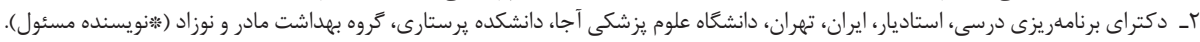
آدرس الكترونيك: sh.aliyari@ajaums.ac.ir

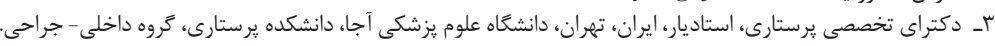

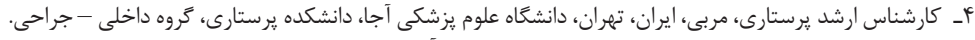

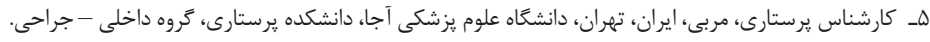


كه دستورالعمل اخير در اكتبر ها ـ ا مجدداً به روز رسانى شده

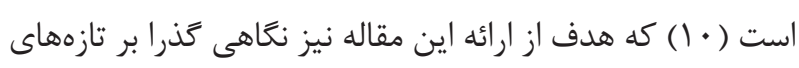

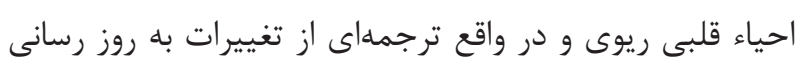
شده احياء پايه مىباشد.

\section{مواد و روشها}

جهت نغارش مقاله حاضر از متن منتشر شده از دستورالعمل

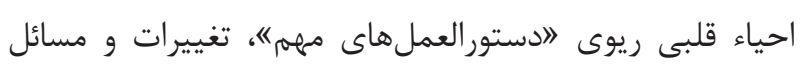

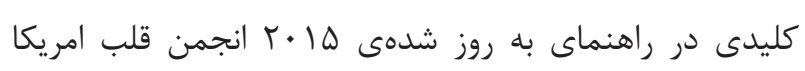
براى احياى قلبى - (AHA: American Heart Association) ريوى و مراقبت اورزانسى قلبى عروقى ECC: Emergency) برى (A) Cardiovascular Care) دهندكان فر آيند احياء و نيز براى مربيان انجمن قلب امريكا تدوين

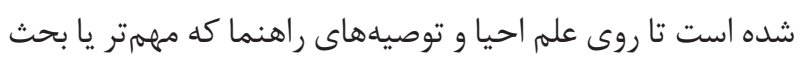
انكيزتر هستند، يا مواردى كه به تغيير عمل احيا يا آموزش احيا

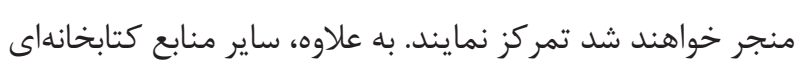

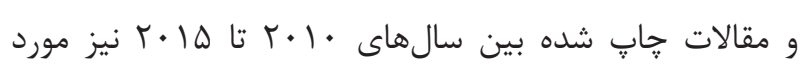
استفاده قرار كرفته است.

\section{يافتهها}

در دستورالعمل ها إك، زنجيرههاى بقا به صورت جداكانه و در

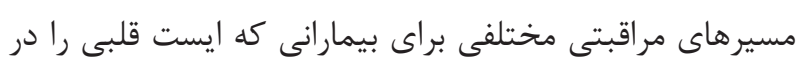

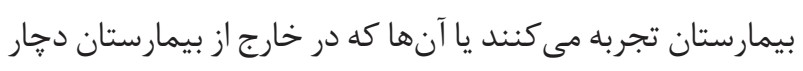
ايست قلبى مىشوند، در نظر كرفته شده است.

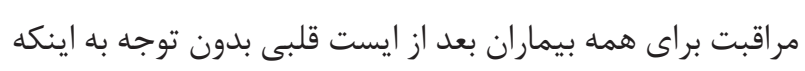

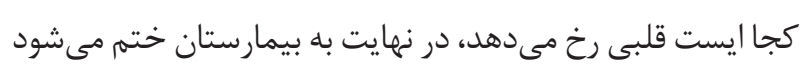

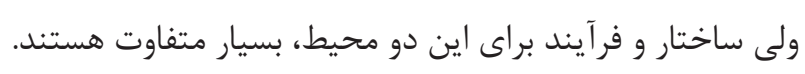

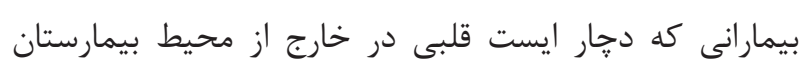

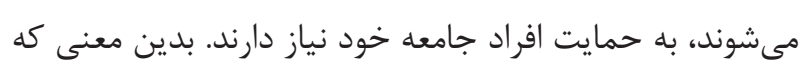

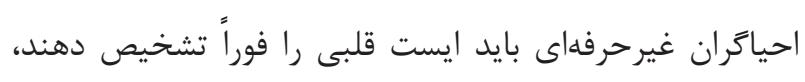

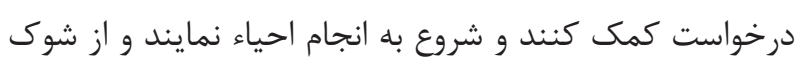
الكتريكى در صورتى كه در دسترس باشد، استفاده نمايند تا

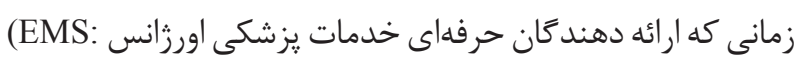

يكى وضعيت اورزانسى، حاد و مهمى است كه در هر جايى جه

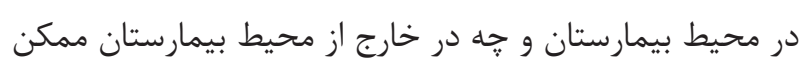
است ايجاد شود و اخر عمليات احياء قلبى و ريوى (CPR: Cardio سريعاً و درست انجام شود ميزان Pulmonary Resuscitation)

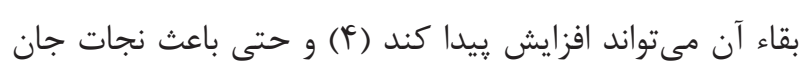

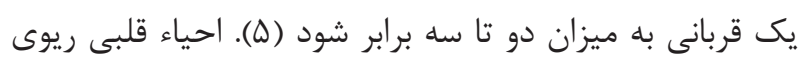

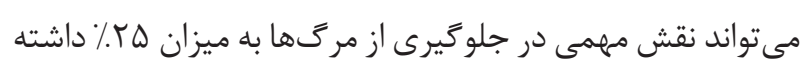

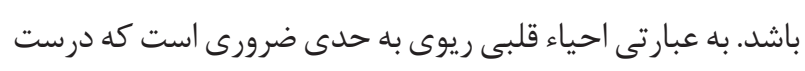

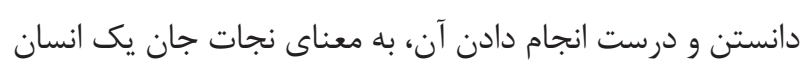

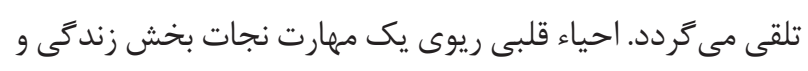
در واقع يك تكنيك حفظ حيات است كه شامل استفاده از ماساز قلبى قفسه سينه و تنفس مصنوعى و استفاده از دفيبر يلاتور جهت برقرارى جريان خون و اكسيزناسيون در طول ايست قلبى مى باشد ولند

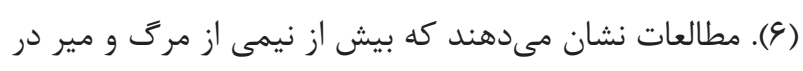

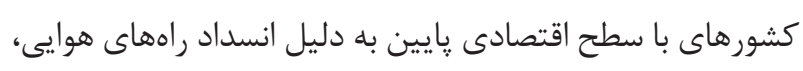
نارسايى تنفسى و خونريزى غير قابل كنترل اتفاق مى افتد كه تمام

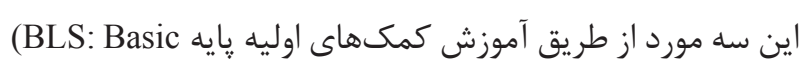
قابل جبران است (V) Life Support) مهارت بنيادى و نجات بخش براى احياء است و نقش تعيين كننده

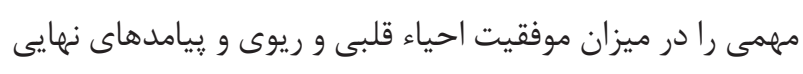

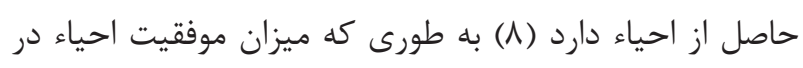

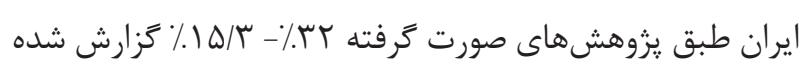

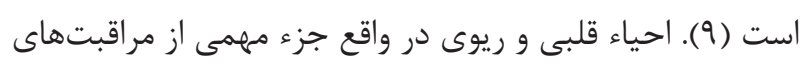
ضرورى است كه بايستى جهت تمامى مصدومين حمله قلبى بدون

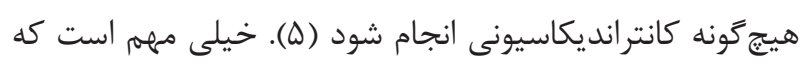

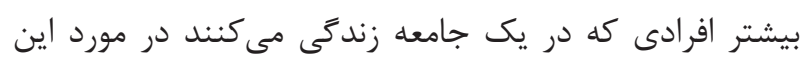

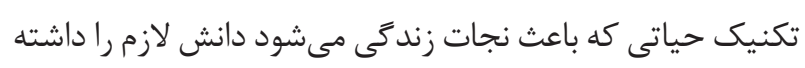

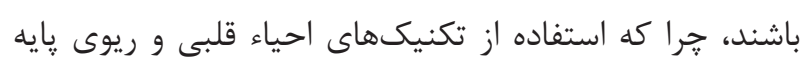

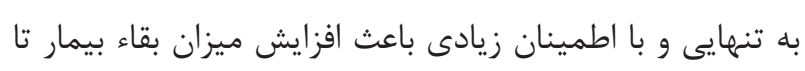

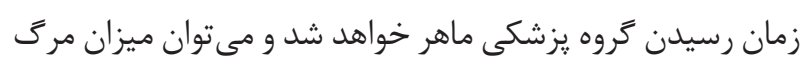

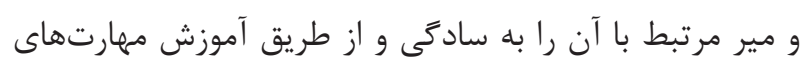
ساده احياء قلبى ريوى كاهش داد (9). لذا، جهت آموزش عموم

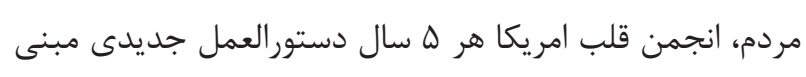

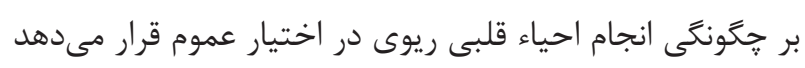


كَيرند.در مقابل، بيمارانى كه دجار ايست قلبى در داخل بيمارستان شامل يزشكان، يرستاران، متخصصان تنفسى و غيره وابسته

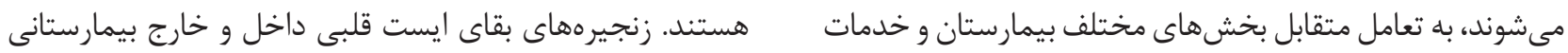

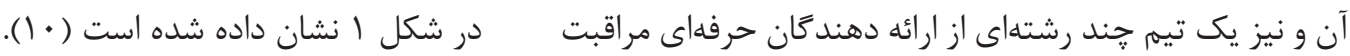

IHCA
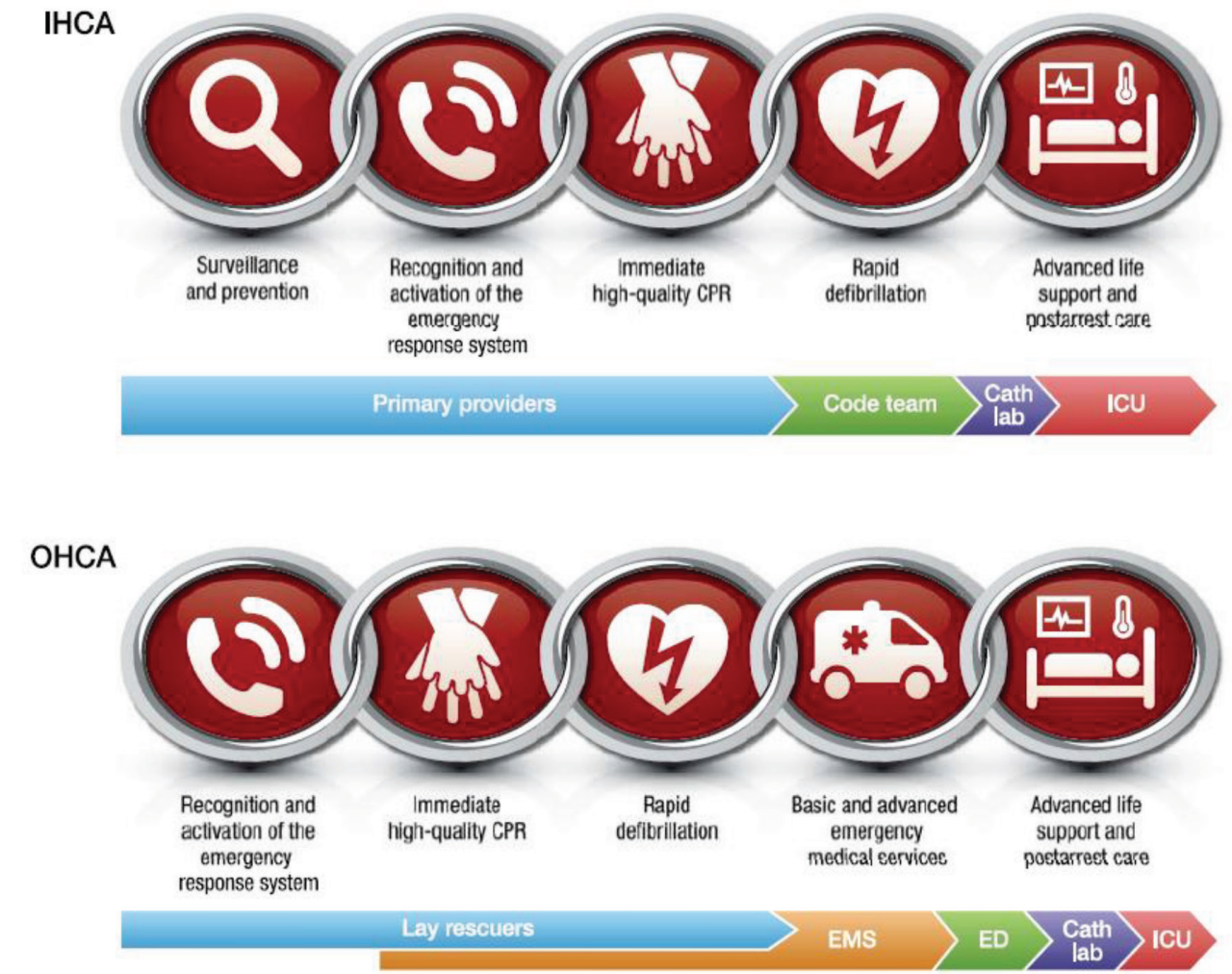

ايست قلبى داخل بيمارستانى

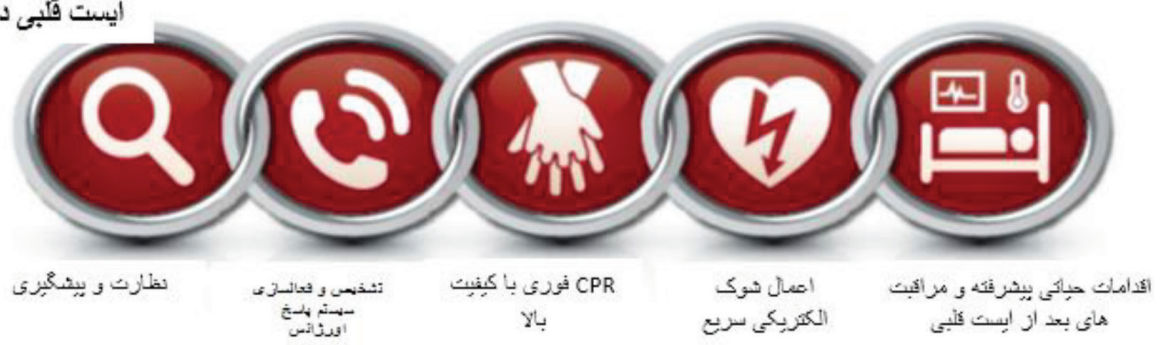

Pimay providers

Code team $\left.\sum_{\mathrm{Iab}}\right\rangle \mathrm{ICU}$

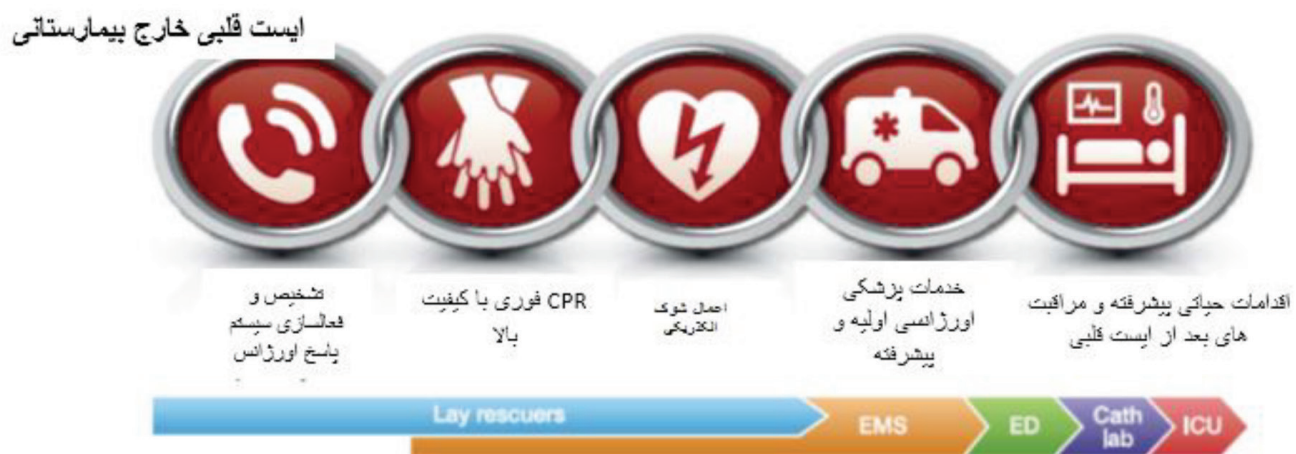

شكل ا- زنجيرههاى بقاى ايست قلبى داخل و خارج بيمارستانى ( • ) 


$$
\begin{aligned}
& \text { شرايط استفاده از شوك الكتريكى نيز فراهم مىشود). } \\
& \text { مراحل اجراى احياء قلبى ريوى پايه بر اساس دستوالعمل ها • }
\end{aligned}
$$

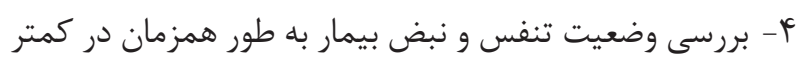

$$
\begin{aligned}
& \text { از · •انيه } \\
& \text { ه- در صورت تشخيص ايست قلبى، شروع فورى عمليات احياء }
\end{aligned}
$$

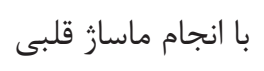

$$
\begin{aligned}
& \text { و- بررسى راه هوايى از نظر باز بودن و دادن تنفس مصنوعى } \\
& \text { به ترتيب زير مىباشد: } \\
& \text { ا - تائيد ايمنى محل } \\
& \text { ץ- بررسى وضعيت هوشيارى و پاسخدهى بيمار } \\
& \text { "- در صورت عدم پاسخدهى، درخواست كمك و فعال نمودن } \\
& \text { سيستم پاسخ اورزانس با استفاده از موبايل (در اين فاصله }
\end{aligned}
$$

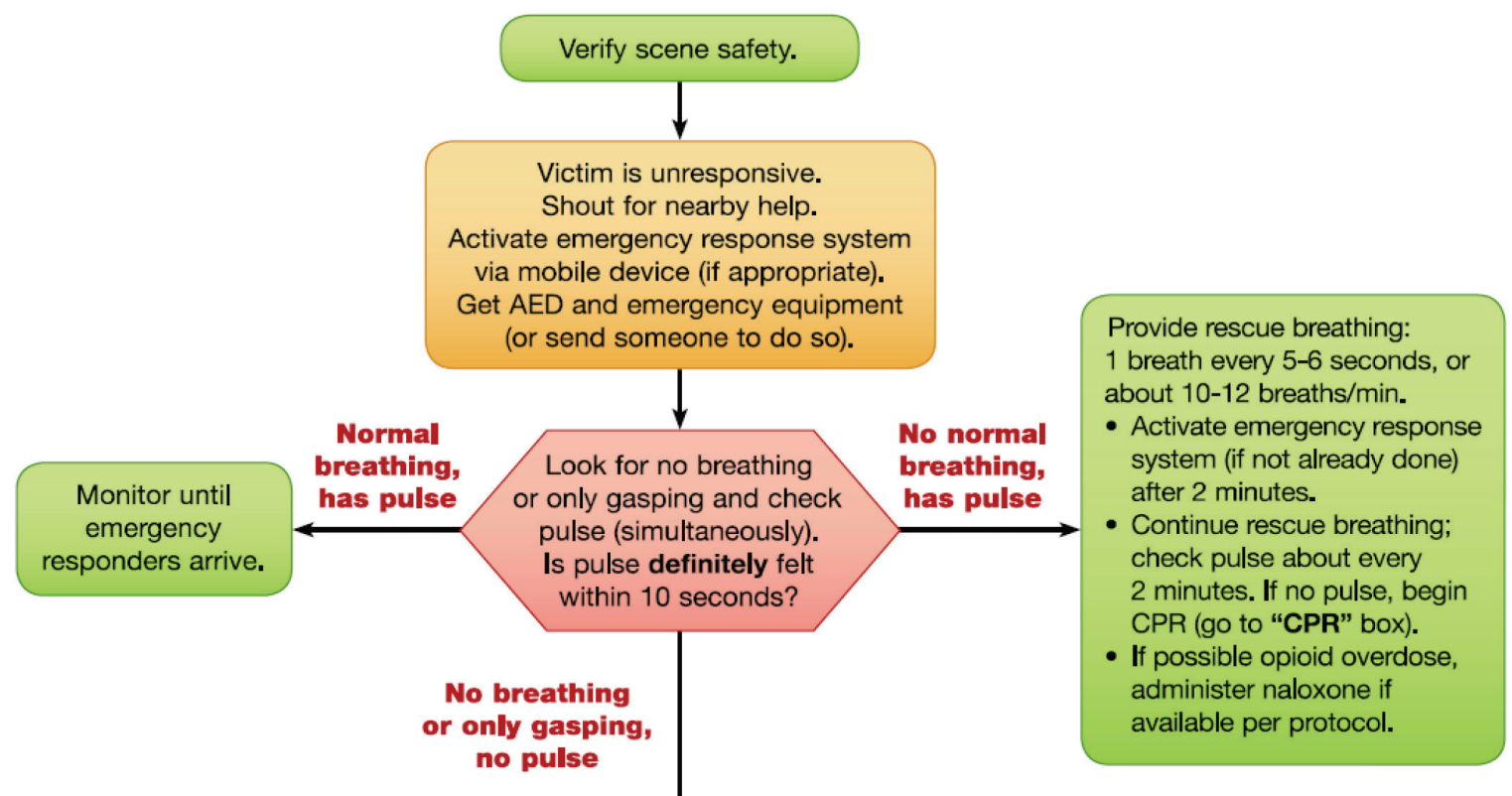

By this time in all scenarios, emergency response system or backup is activated, and AED and emergency equipment are retrieved or someone is retrieving them.

Begin cycles of

30 compressions and 2 breaths.

Use AED as soon as it is available.

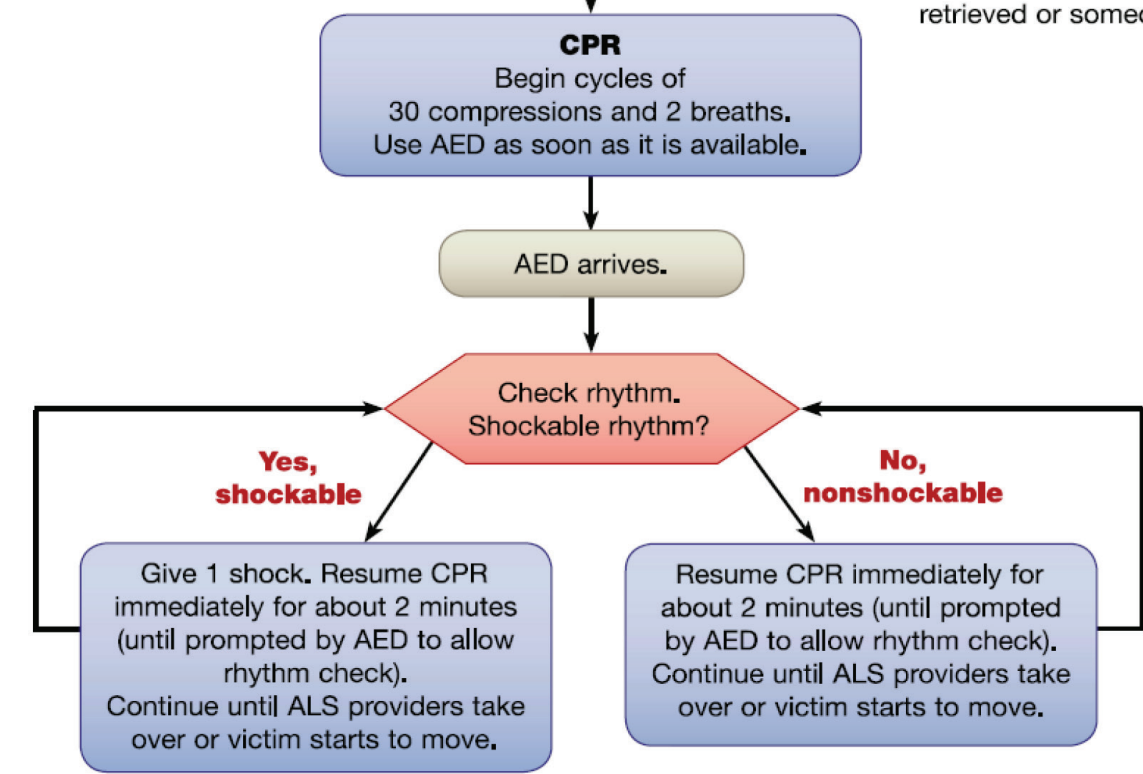

شكل ץ : الكَوريتم اقدامات حياتى پايه توسط ارائه دهنده مراقبت بهداشتى در ايست قلبى بز رَسال - به روز شده ها • [ [1] 
است و همجنان بر الكوريتم جامع و در عين حال ساده شده اقدامات حياتى گايه در بزرگسالان، تأكيد دارد. الگوريتم اقدامات حياتى گيايه بزرگسالان اصلاح شده است تا نشان دهنده اين واقعيت باشد كه احياگران مىتوانند به سيستم اورزانس اطلاع دهند (به طور مثال با استفاده از يك تلفن همراه) بدون اينكه خود قربانى را تركى نمايند.

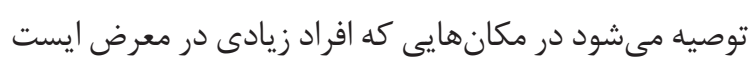
قلبى قرار دارند از دفيبريلاسيون جهت استفاده عموم مردم در موارد وقوع ايست قلبى استفاده گردد. توصيه شده است در صورتى كه احياگر غير حرفهاى، يك قربانى بدون ״اسخ را بيابد كه نفس نمى كشد يا تنفس نرمالى ندارد

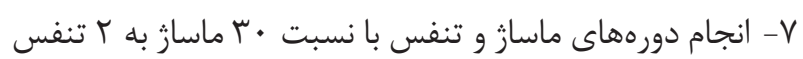

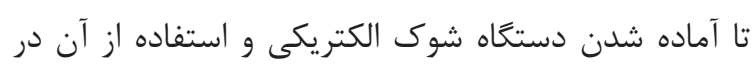
صورت نياز و دسترسى و ادامه انجام احياء تا رسيدن گروه امداد ( • (). الگوريتم اصلاح شده مراحل فوق در شكل ب نشان داده شده است.

نكات كليدى و تغييرات اساسى در اقدامات حياتى پايه در بزرَسالان و كيفيت احياى قلبى ريوى، توسط احياگران غيرحرفهاى در دستورالعمل هاى ها • r به شرح ذيل مىباشد:

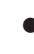
• زنجيره بقاء بزر گسالان در خارج از بيمارستان، در دستور العمل جديد همانند دستورالعمل سال • | · ب بوده و تغييرى نكرده

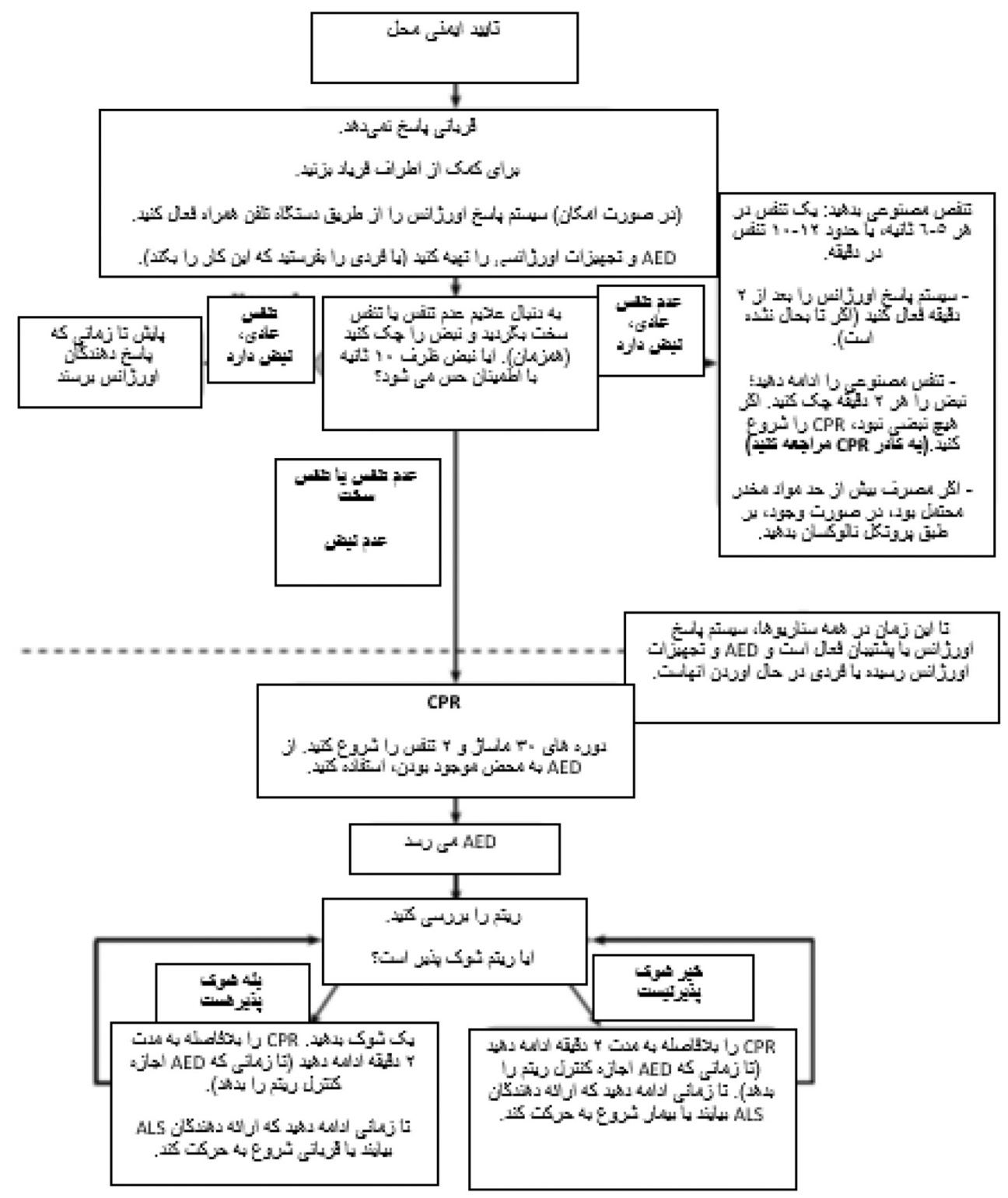


احياگر، سيستم پاسخ اورزانس را فعال مى كند، در حالى كه

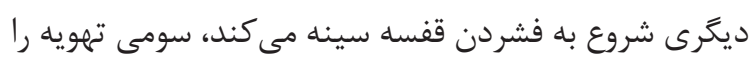

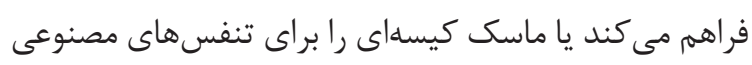

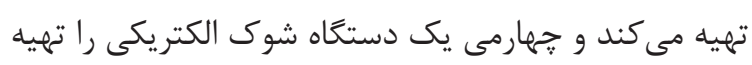

$$
\text { و تنظيم مىنمايد) }
$$

تأكيد زيادى بر احياى قلبى ريوى با كيفيت با استفاده از اهداف عملكردى شده است (فشار با سرعت و عمق مناسب، امكان

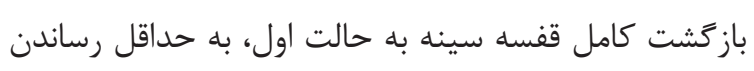
وقفهها در فشارها و اجتناب از تهويه اضافى).

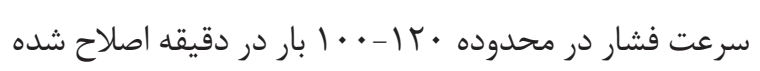
است. عمق فشار براى بزركسالان به دست كم ب اينج (ه سانتى

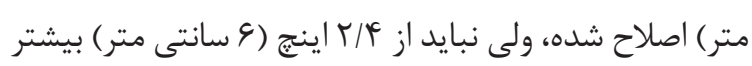
شود. براى امكان باز گشت كامل ديواره قفسه سينه بعد از هر فشار، احياكران بايد از خم شدن روى قفسه سينه در بين فشارها اجتناب كنند. بر به حداقل رساندن وقفهها در حين انجام ماساز تأكيد شده

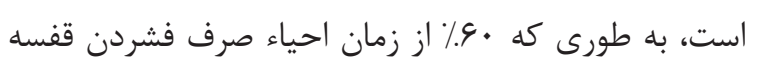
سينه با حداقل وقفه در حين انجام آن شود.

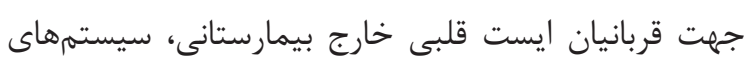
خدمات يزشكى اورزانس بايستى علاوه بر انجام اقدامات لازم

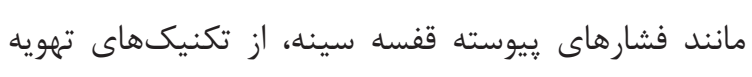
غيرفعال نيز در جهت مراقبت از اين بيماران استفاده نمايند.

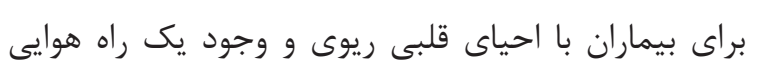

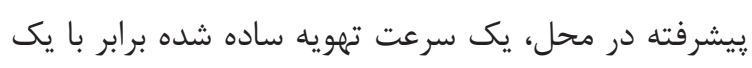

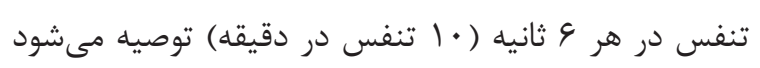

به طور كلى مواردى كه بايد احيا گَران در نظر داشته باشند و

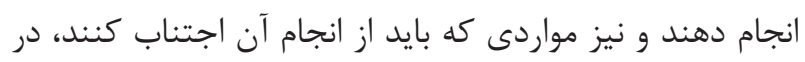
جدول شماره ا ارائه شده است.
(بريده نفس كشيدن) و پاسخ نمى دهد، سيستم پِاسخ اورزانس

$$
\text { را فعال نموده و احياى قلبى ريوى را شروع كند. }
$$

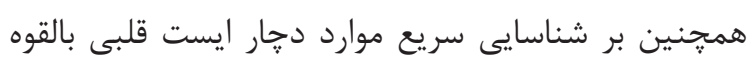

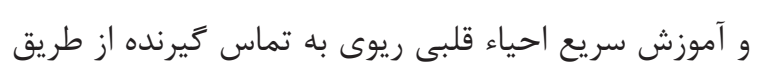
سيستم קاسخ اورزانس، تأكيد شده است.

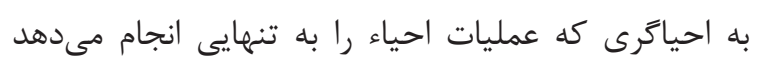

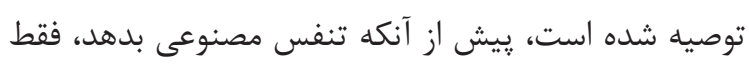

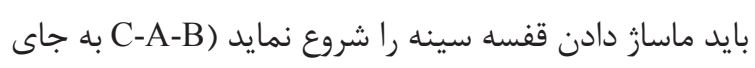

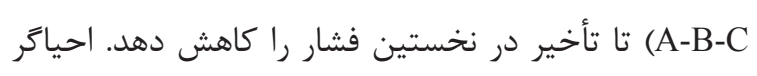

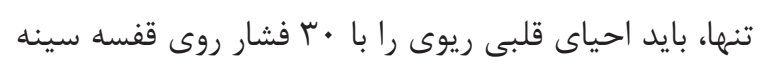
به همراه r تنفس مصنوعى شروع نمايد. بر احياى قلبى ريوى باكيفيت تأكيد شده است بدين معنا كه نمان

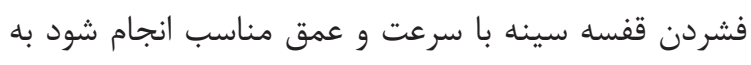

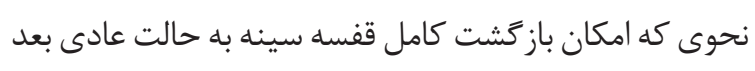

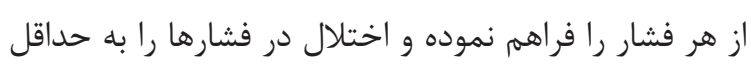
برساند و از تهويه (هوا رسانى) اضافى اجتناب نمايد.

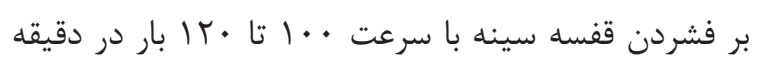
توصيه شده است.

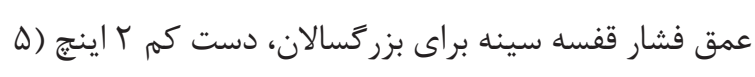

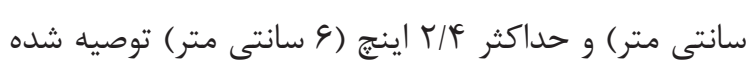
تزريق نالوكسان توسط ناظران در اورزانس هاى مربوط به مواد مخدر، بالقوه تهديد كننده حيات بايستى در نظر كرفته شون

نكات كليدى و تغييرات اساسى در اقدامات حياتى پِايه در بزركسالان و كيفيت احياى قلبى ريوى، توسط ارائه دهندكان

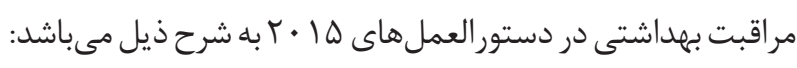

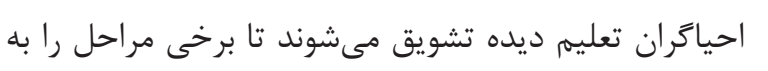

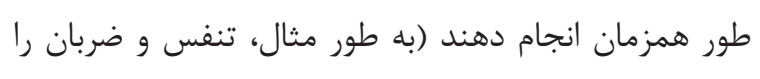

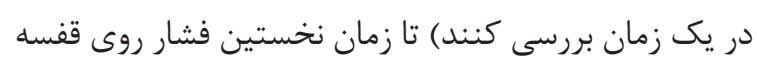
سينه را كاهش دهند.

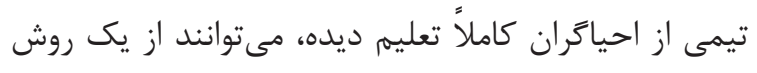

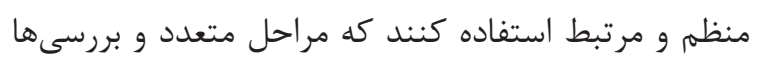

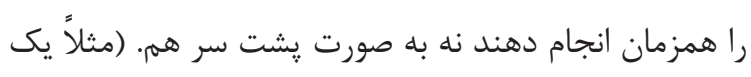


جدول (- بايدها و نبايدهاى BLS مربوط به CPR باكيفيت ( • )

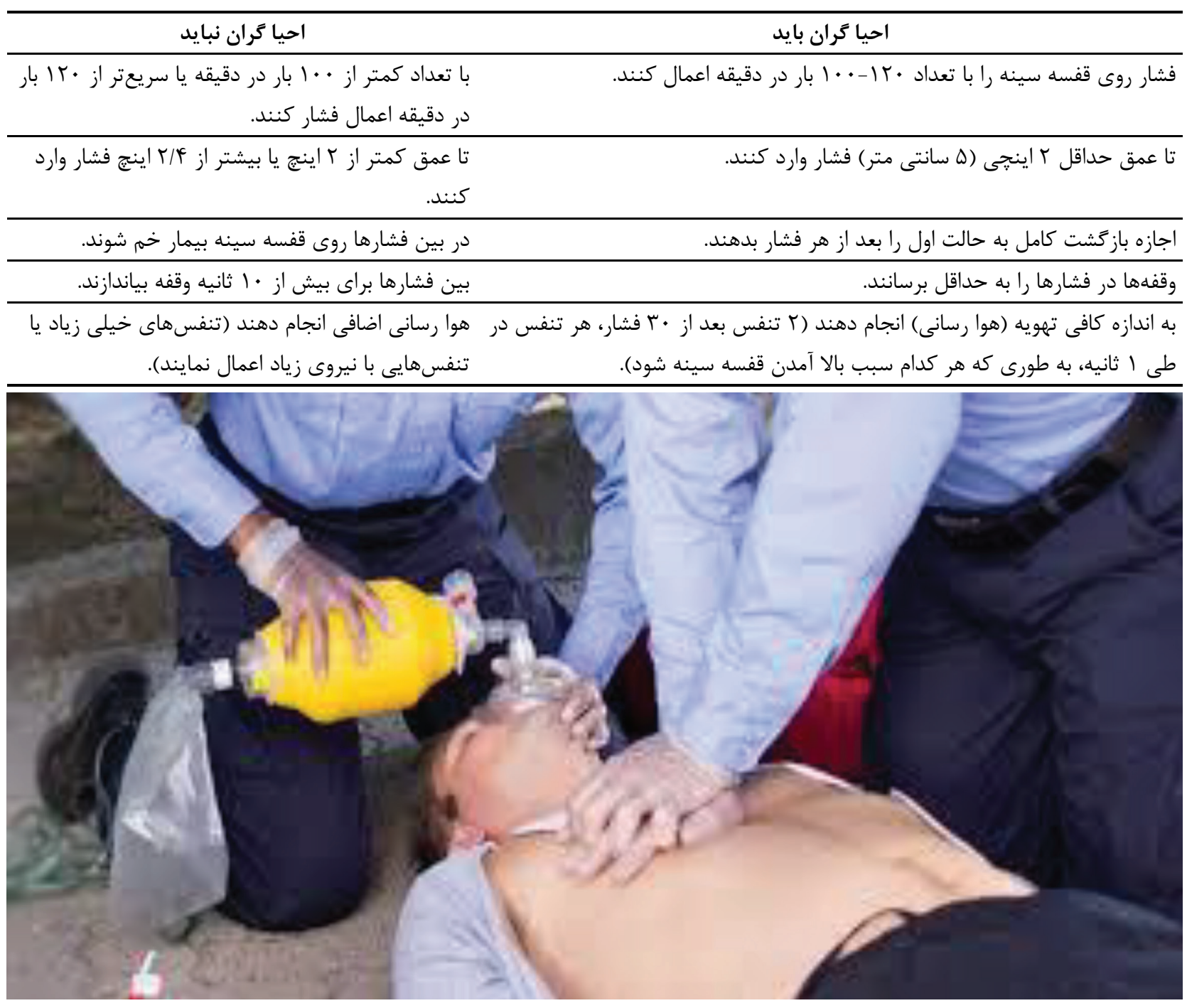

در دسترس عموم، نيازمند أ مؤلفه ضرورى است: (الف) شناسايى

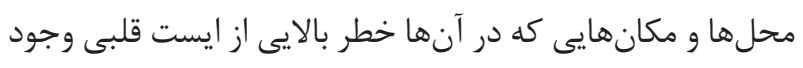

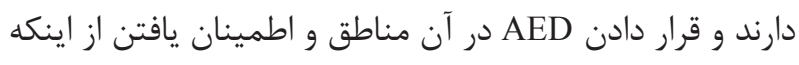

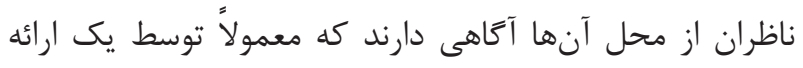

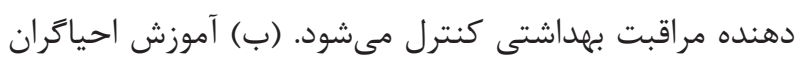
״يش بينى شده جهت انجام احياى قلبى ريوى و استفاده آنها از AED

محلى (د) وجود يك برنامه براى بهبود كيفى مستمر.

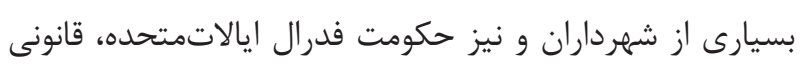

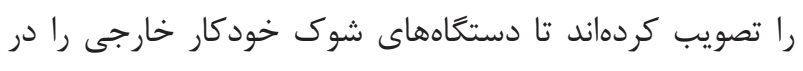
ساختمان هاى شهرى، حوزهاى قضايى عمومى بزرى، فرود

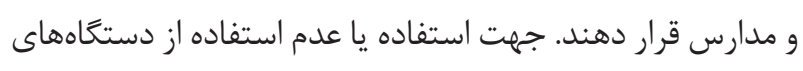

كه براى احياگران غيرحرفهاى و كاركنان حرفهاى ارائه دهندكان مراقبت بهداشتى مشابه هستند، با علامت ستاره (**) نمايش كران داده شدهاند. به كاركيرى دستخاههاى شوك خودكار خارجى توسط احياكر

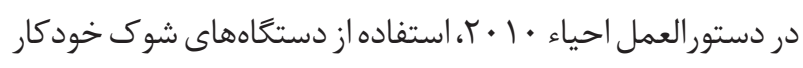

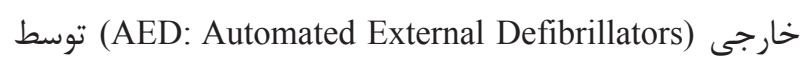
پاسخ دهندكان مسئول و آموزش ديده انجام مى گرفت (1) (1).

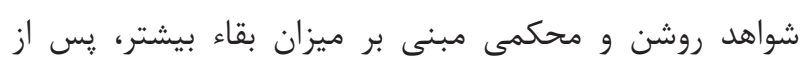

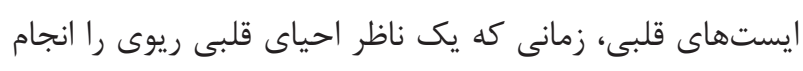

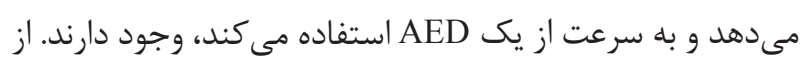
اين رو، دسترسى فورى به يك دستخاه شوك الكتريكى، يك جزء اصلى سيستم مراقبتى است. بيادهسازى يك برنامه دفيبر يلاسيون 
احياى قلبى ريوى فقط فشارى را تا زمان رسيدن يك دفيبريلاتور

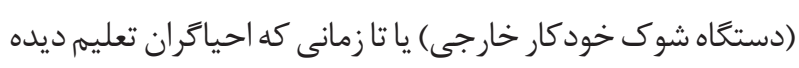

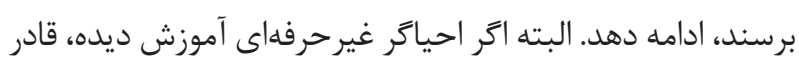

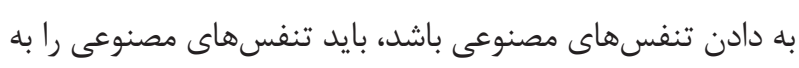
نسبت • r ماساز به r تنفس اضافه نمايد (• (1).

\section{*سرعت فشار قفسه سينه}

تعداد فشارهاى قفسه سينه اعمال شده در هر دقيقه در طى احياى فعنه سينه

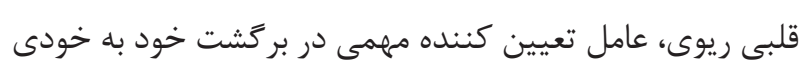

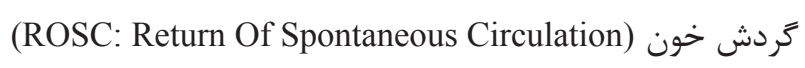
و بقاى بيمار با عملكرد خوب سيستم عصبى است. تعداد واقعى

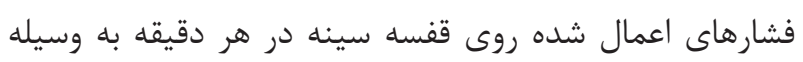

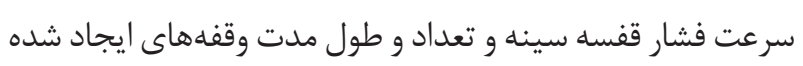

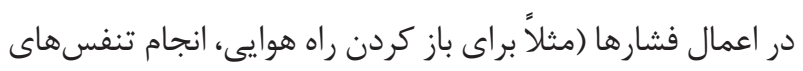

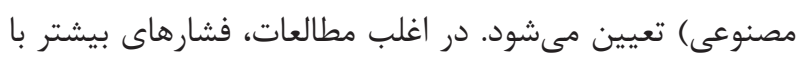

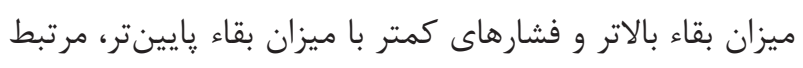

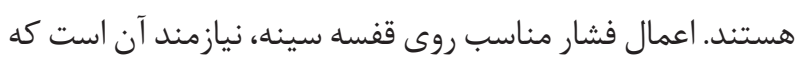

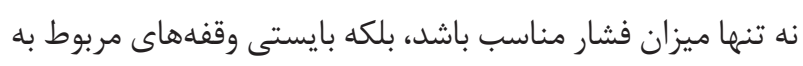

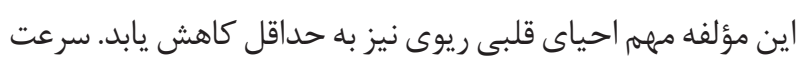

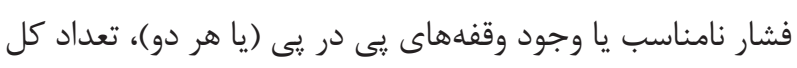

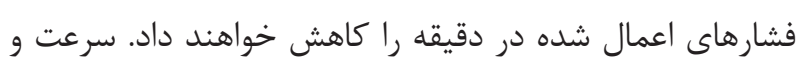

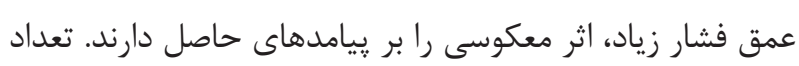
فشارهاى اعمال شده متأثر از سرعت فشار (تعداد فشار قفسه سينه رئه

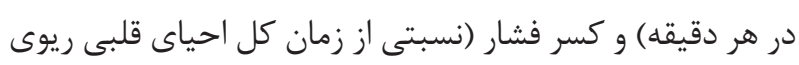

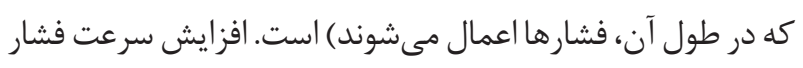

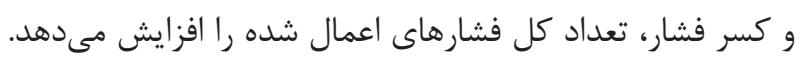
كسر فشار با كاهش تعداد و طول مدت هر گَونه وقفه در فشارها، بهبود مى يابد. مشابه اين مورد را مىتوان در مسافرت باد با اتومبيل

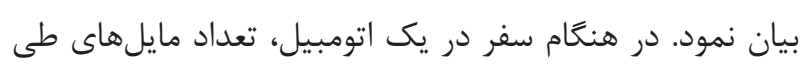

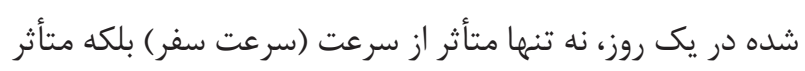

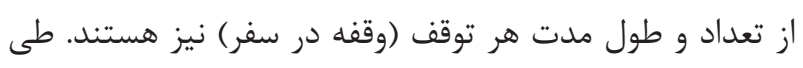

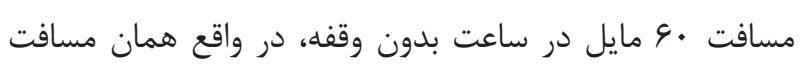

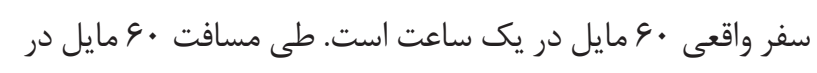

شوك خودكار خارجى در منازل شواهد ناكافى وجود دارد. قربانيان

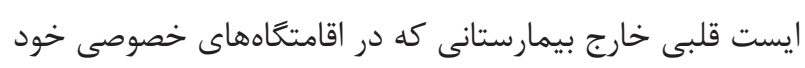

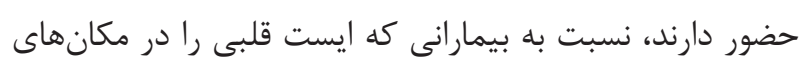

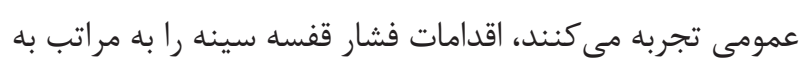
ميزان كمترى دريافت مى كنند. آموزشهاى به موقع ارائه شده

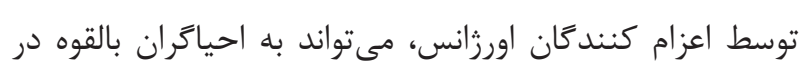

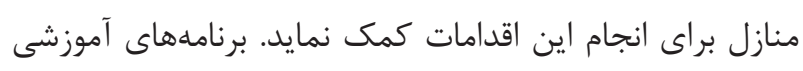

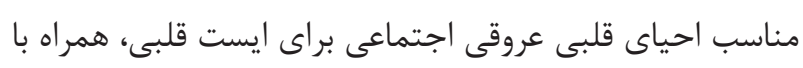

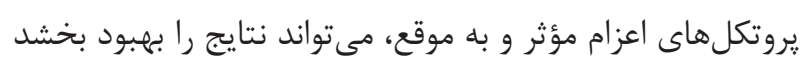

شناسايى افراد مبتلا به تنفس هاى نامنظم (Agonal gaspping) كاهى اوقات قربانيان ايست قلبى دستخوش حالت حملات شبيه

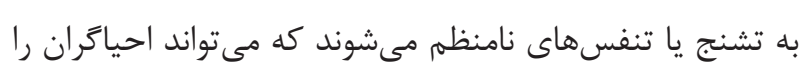

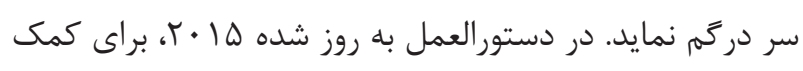
به ناظران در تشخيص ايست قلبى، اعزام شوند

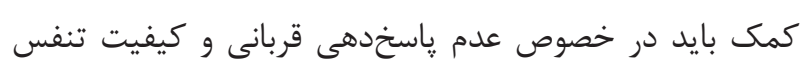

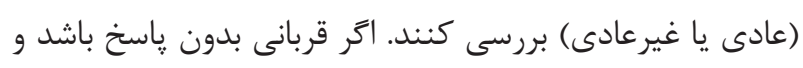
تنفس نداشته باشد يا تنفس غيرعادى داشته باشد، احياكر و اعزام شونده بايد فرض كنند كه قربانى دجار ايست قلبى شده است. اعزام شوندكان بايد طورى آموزش ببينند كه عدم رياسخدهى باني

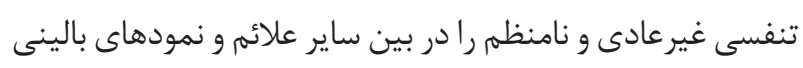

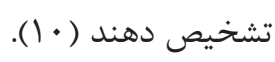

\section{*أكيد بر فشار قفسه سينه}

اجراى احياى قلبى ريوى فقط به صورت ماساز، براى يك احياكر

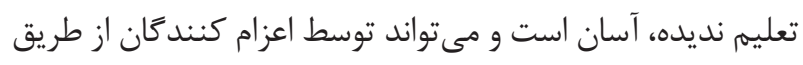
تلفن به صورت مؤثرى هدايت شود. به علاوه، ميزان بقاء ناشى از

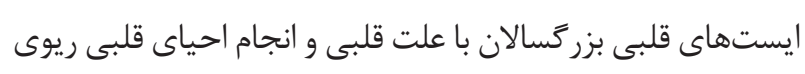

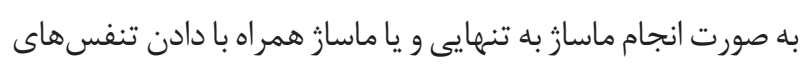
مصنوعى، (هنخامى كه قبل از رسيدن خدمات يزشكى اورزانس انجام

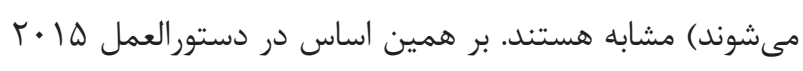

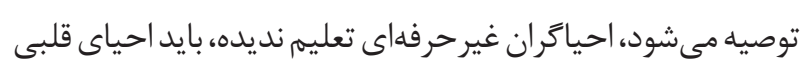
ريوى فقط فشارى (فشردن قفسه سينه) را با يا بدون هدايت اعزام كننده، براى قربانيان بزر گسال با ايست قلبى انجام دهند. احياگر بايد 
براى كسر فشار قفسه سينه تعريف نشده است. افزايش كسر فشار

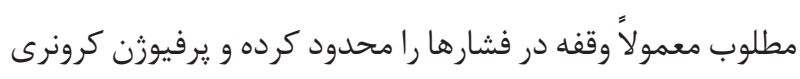
و كردش خون در طى احياى قلبى ريوى را بيشتر مىسازد (• (1).

*جويز نالوكسان توسط ناظر در موارد اورزانسى تهديد كننده حيات در معتادان

براى بيماران شناخته شده يا مشكوك به اعتياد به مواد مخدر

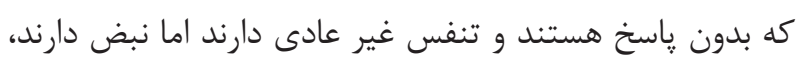
لازم است احياكران غير حرفهاى كه به خوبى تعليم ديدهاند و ارائه

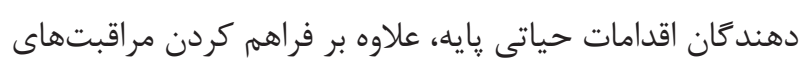

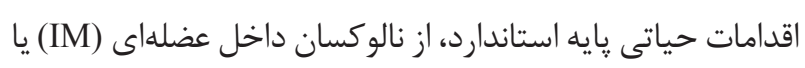

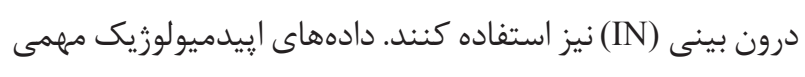

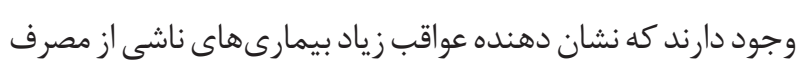

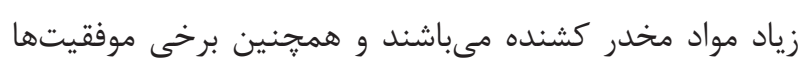

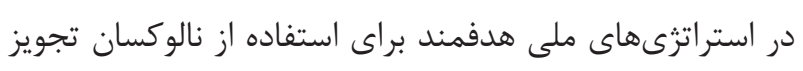

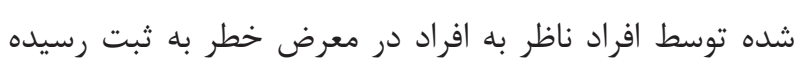

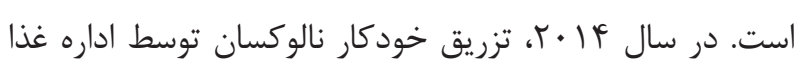
و داروى ايالاتمتحده (US Food and Drug Administration) براى استفاده توسط احياكر ان غير حرفهاى و ارائه دهندَان خدمات بهداشتى تأييد شد ( • (1).

\section{تشخيص فورى و فعال سازى سيستم پاسخ اورزانس}

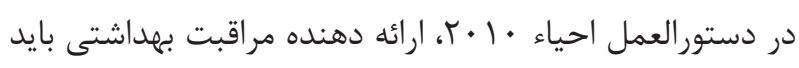

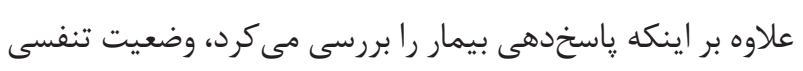

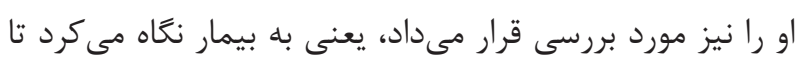

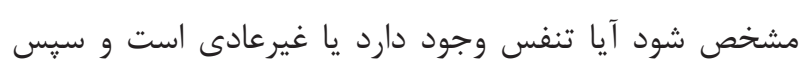
جهت درخواست كمك اقدام مىنمود ( • (). در دستور العمل احياء

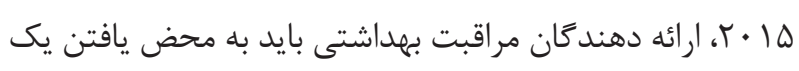

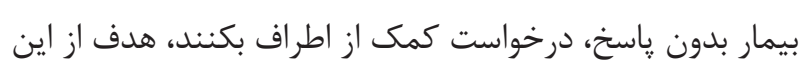

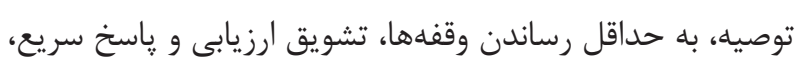
مؤثر و همزمان به جاى يك رويكرد كام به كام و كند است ( • (1).

نخستين شوك در برابر نخستين احياى قلبى ريوى

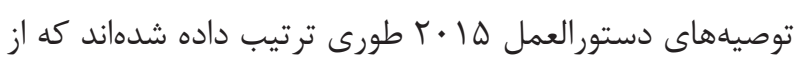

• ه مايلى در يك ساعت. هر خه توقف ها بيشتر و طولانىتر باشند،

مسافتهاى طى شده واقعى كمتر خواهند بود (• (1).

\section{* عمق فشار قفسه سينه}

فشار قفسه سينه به واسطه افزايش فشار درون قفسه سينه و فشار

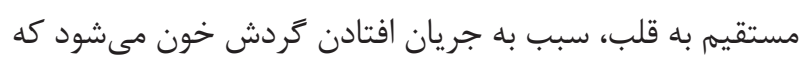
باعث رساندن اكسيرن به قلب و مغز مى گردد. احياگر ان اغلب قفسه سينه را با شدت و عمق كافى فشار نمى دهند (• (1).

* بركشت قفسه سينه به حالت قبل

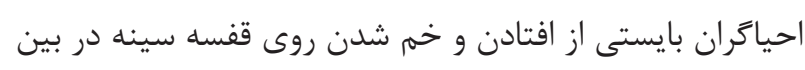
فشارها اجتناب كنند تا امكان بازخشت كامل ديواره قفسه سينه را براى بزر كسالان دجار ايست قلبى فراهم كنند. بر خشت كامل

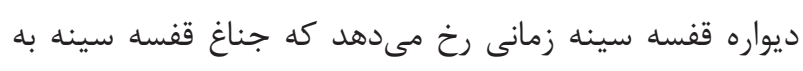

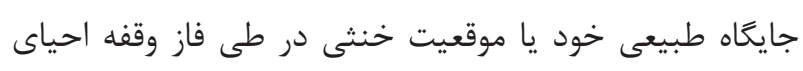

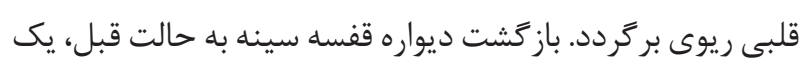

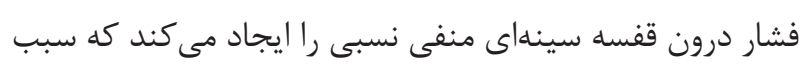

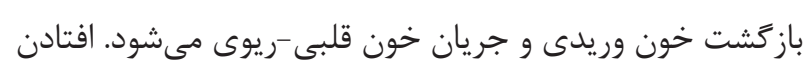
روى قفسه سينه بين فشارها، مانع بازگشت كامل ديواره قفسه

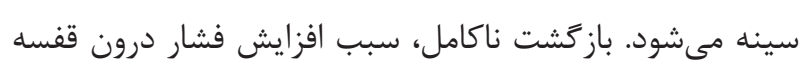
سينهاى و كاهش بازگشت خون وريدى، كاهش فشار يرفيوزئن قلبى و در نتيجه كاهش جريان خون ميوكارد مىشود و مسلماً مى تواند بر ييامدهاى احياء تأثير بحذارد (• • ().

\section{*به حداقل رساندن وقفهها در فشارهاى قفسه سينه}

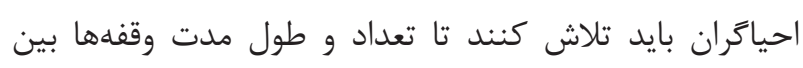

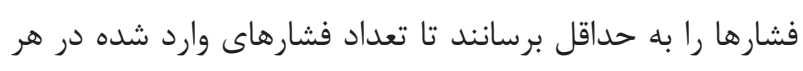

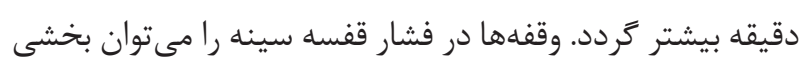

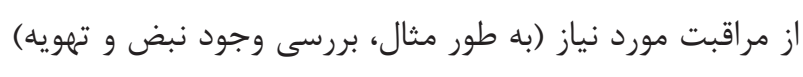

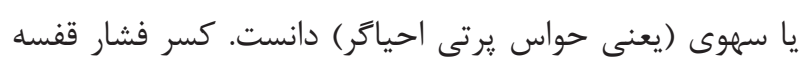

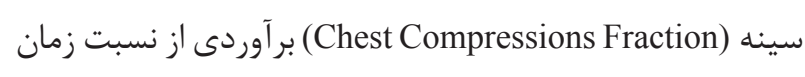
ماساز قفسه سينه به كل زمان احياء است كه در طى آن فشارها

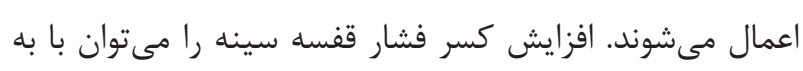
حداقل رساندن وقفه در فشار قفسه سينه محقق نمود. هدف بهينه 
نيز استانداردهاى عملكرد احياگر مىباشد. اين دادههاى مهمم را مى توان در طول زمان واقعى احياء براى كزارشدهـى بعد از احياء و براى برنامههاى بهبود كيفيت سيستم به كار برد. حفظ تمركز

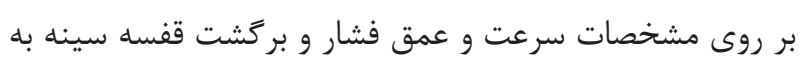
حالت قبل در طى احياى قلبى ريوى، در عين به حداقل رساندن

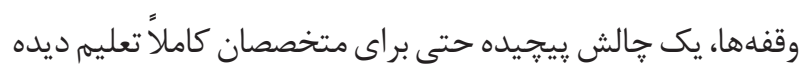

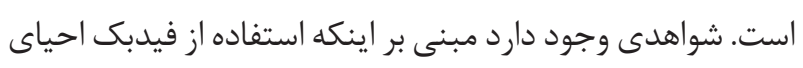

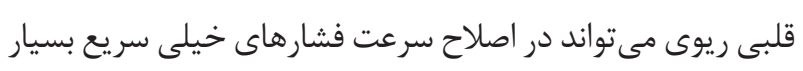

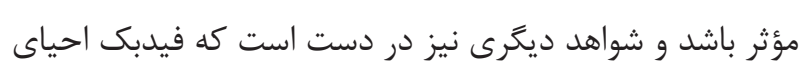

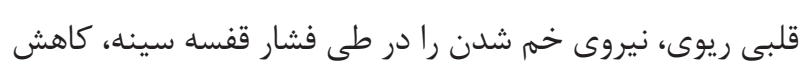

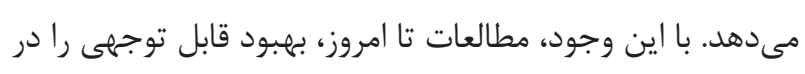

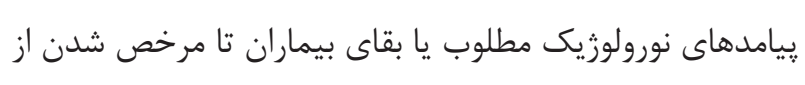

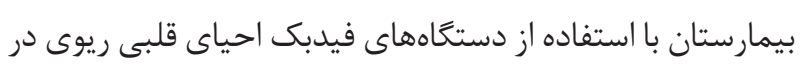
طى بيشامدهاى ايست قلبى واقعى نشان ندادهاند ( • ().

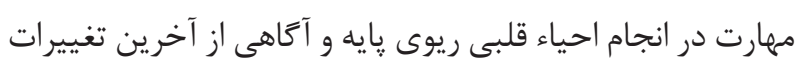

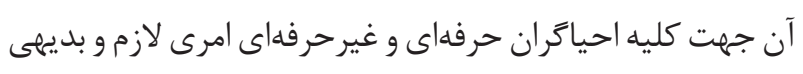
است. اميد است كه با ترجمه احياء قلبى ريوى يايه بتوان كام مؤثرى در بيشبرد احياء قلبى ريوى مؤثر جهت عموم مردم ارائه داد.

\section{تشكر و قدردانى}

اين مقاله بركرفته از پاياننامه كارشناسى ارشد رشته يرستارى

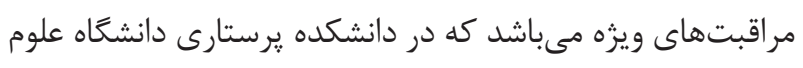

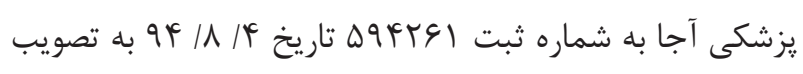
رسيده است.

\section{References}

1- Chaves WG, Diaztagle JJ, Sprockel JJ, Hernández JI, Benavidez JM, Henao DC, et al. Factors associated with mortality in patients with decompensated heart failure. Acta Medica Colombiana. 2014;39(4):314-20.

2- Travers AH, Rea TD, Bobrow BJ, Edelson DP, Berg RA, Sayre MR, et al. Part 4: CPR overview: 2010 American Heart Association Guidelines for Cardiopulmonary Resuscitation and Emergency Cardiovascular Care. Circulation. 2010;122(18 Suppl 3):S676-84. DOI: 10.1161/CIRCULATIONAHA.110.970913 PMID: 20956220

SD 3- Ong ME, Chung WL, Mei JS. Comparing attitudes of the public
احياى قلبى ريوى و شوك الكتر يكى زود هنغام يشتيبانى مى كنند،

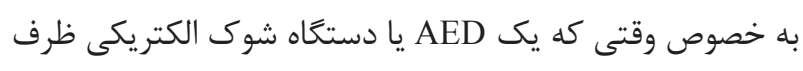

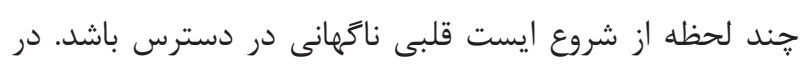

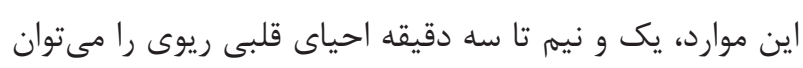

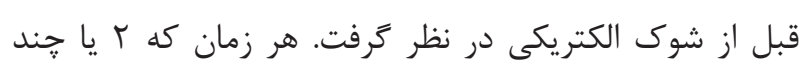

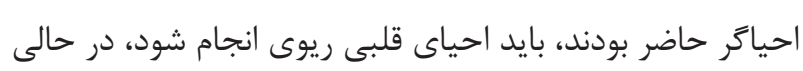

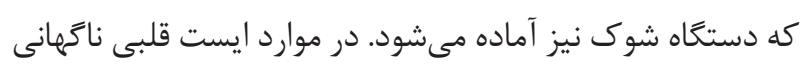

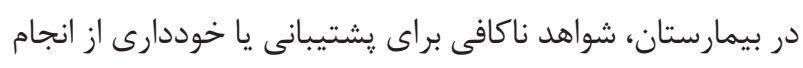

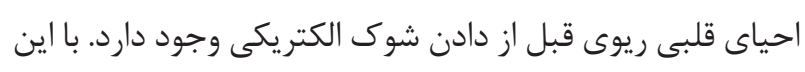

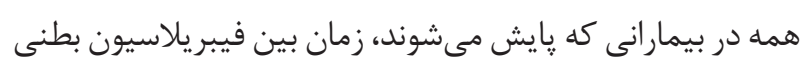

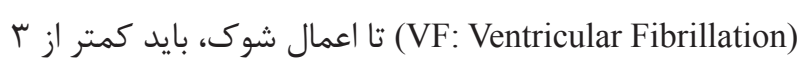
دقيقه باشد و احياى قلبى ريوى در حين آماده كردن دستگاه

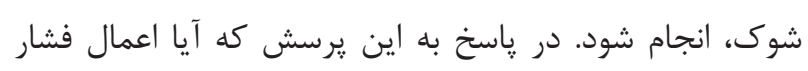

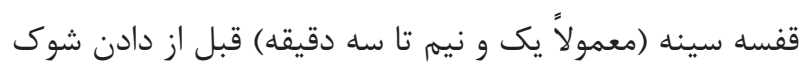

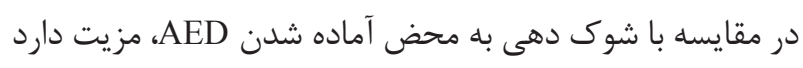

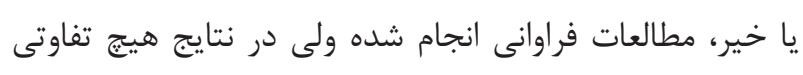
نشان داده نشده است (•) (1).

\section{بازخورد فشار قفسه سينه (Chest Compression Feedback)} ممكن است استفاده از دستخاههاى فيدبك سمعى - بصرى در طى احياى قلبى ريوى براى بهينه سازى (Audiovisual)

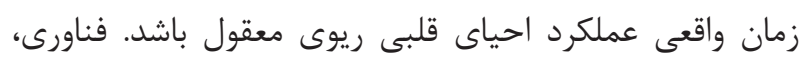

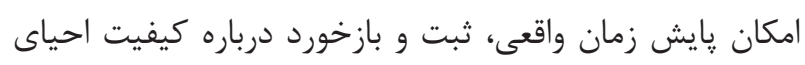

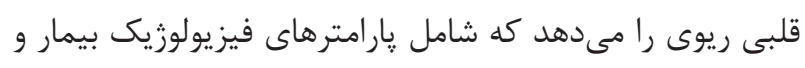

and medical staff towards witnessed resuscitation in an Asian population. Resuscitation. 2007;73(1):103-8. DOI: 10.1016/j. resuscitation.2006.08.007 PMID: 17254693

4- Abbas A, Bukhari SI, Ahmad F. Knowledge of first aid and basic life support amongst medical students: a comparison between trained and un-trained students. J Pak Med Assoc. 2011;61(6):6136. PMID: 22204227

5- Beck JD, Eke P, Heiss G, Madianos P, Couper D, Lin D, et al. Periodontal disease and coronary heart disease: a reappraisal of the exposure. Circulation. 2005;112(1):19-24. DOI: 10.1161/ CIRCULATIONAHA.104.511998 PMID: 15983248 
6- Okonta KE, Okoh BAN. Theoretical knowledge of cardiopulmonary resuscitation among clinical medical students in the University of Port Harcourt, Nigeria. Africa J Med Health Sci. 2015;14(1):42. DOI: 10.4103/2384-5589.153391

7- Merchant A, Outhay M, Gonzalez-Calvo L, Moon TD, Sidat M, Taibo CL, et al. Training laypersons and hospital personnel in basic resuscitation techniques: an approach to impact the global trauma burden in Mozambique. World J Surg. 2015;39(6):1433-7. DOI: 10.1007/s00268-015-2966-z PMID: 25663007

8- Mardegan KJ, Schofield MJ, Murphy GC. Comparison of an interactive CD-based and traditional instructor-led Basic Life Support skills training for nurses. Aust Crit Care. 2015;28(3):1607. DOI: 10.1016/j.aucc.2014.06.001 PMID: 25012764

9- Adib-Hajbaghery M, Azizi-Fini E. Longitudinal study of cardiopulmonary resuscitation knowledge and skills among nurse interns of Kashan university of medical sciences. Iran J Med Edu. 2013;13(2):134-45.

10- Guidelines 2000 for Cardiopulmonary Resuscitation and Emergency Cardiovascular Care. Part 12: from science to survival: strengthening the chain of survival in every community. The American Heart Association in collaboration with the International Liaison Committee on Resuscitation. Circulation. 2000;102(8 Suppl):I358-70. PMID: 10966681

11- Billi JE, Shuster M, Bossaert L, de Caen AR, Deakin CD, Eigel B, et al. Part 4: Conflict of interest management before, during, and after the 2010 International Consensus Conference on Cardiopulmonary Resuscitation and Emergency Cardiovascular Care Science With Treatment Recommendations. Circulation. 2010;122(16 Suppl 2):S291-7. DOI: 10.1161/CIRCULATIONAHA.110.970962 PMID: 20956252. 


\title{
New Aspects in Basic Cardiopulmonary Resuscitation According to the 2015 guideline
}

\author{
Abdi. A ${ }^{1}, *$ Aliyari. Sh${ }^{2}$, Pishgooie. SA ${ }^{3}$, Seyyed Mazhari. $\mathrm{M}^{4}$, Nazari. SMR ${ }^{5}$
}

\begin{abstract}
Introduction: Cardiopulmonary resuscitation (CPR) has an effective role in reducing mortality due to respiratory and cardiac arrest and in the case of timely and accurate implementation, it can significantly save lives. Therefore, teaching and learning CPR is one of the most basic and vital skills that a person must learn in life. During the past few years, CPR and first aid in the form of simple and basic education programs have been provided for the public around the world.
\end{abstract}

Objective: The purpose of this paper was discussing the latest findings in CPR.

Materials and Methods: This is a review article based on the translation of the instructions of CPR in American Heart Association in 2015, with an emphasis on CPR, as well as other library materials and articles written between 2010 and 2015.

Results: unprofessional and professional revivalists play a vital role in restoring a person who has undergone cardiopulmonary arrest; therefore, they must be trained in CPR operations in accordance with the latest guideline updates. These changes in 2015 adults' basic life support measures and guidelines for resuscitation include correction of the algorithm with the emphasis on comprehensive simplified algorithm, based on the recommendations of CPR performance by professional and unprofessional revivalists, the use of defibrillation in cardiac arrest by the public, CPR quality, and reduction of delays as much as possible.

Discussion and Conclusion: Knowledge of CPR and its latest changes is obviously necessary to all professional and unprofessional revivalists.

Keywords: Cardiopulmonary Resuscitation, Cardiac Arrest.

Abdi A, Aliyari Sh, Pishgooie SA, Seyyed Mazhari M, Nazari SMR. New Aspects in Basic Cardiopulmonary Resuscitation According to the 2015 guideline. Military Caring Sciences. 2016;3(1).56-67.

Submission: 26/4/2016 Accepted data: 9/5/2016 Published: 15/6/2016

1- Student of MSc in Nursing Critical Care Nursing, Iran, Tehran, AJA University of Medical Sciences, Faculty of Nursing.

2- (*Corresponding author) PhD in Curriculum Studies, Assistant Professor, Iran, Tehran, AJA University of Medical Sciences, Faculty of Nursing,

Maternal Newborn Health Department. Email: sh.aliyari@ajaums.ac.

3- PhD in Nursing, Assistant Professor, Iran, Tehran, AJA University of Medical Sciences, Faculty of Nursing, Medical-Surgical Department.

4- Master of Sciences in Nursing, Instructor, Iran, Tehran, AJA University of Medical Sciences, Faculty of Nursing, Medical- Surgical Department.

5- BSc in Nursing, Instructor, Iran, Tehran, AJA University of Medical Sciences, Faculty of Nursing, Medical- Surgical Department. 